Original Paper http://ajol.info/index.php/ijbcs http://indexmedicus.afro.who.int

\title{
Nutritional intake of Solanum nigrum Linn. leaves fortified with peanut paste consumed at breakfast in rural zones in Côte d'Ivoire
}

\author{
Irène Ahou KOUADIO*, Mathias Kouamé KOFFI and Georgette Amoin KONAN \\ Laboratory of Biochemistry and Food Sciences, UFR Biosciences, University of Félix Houphouet-Boigny, 22 \\ BP 582 Abidjan 22. \\ "Corresponding author; E-mail: irenekouadio@yahoo.fr/djetoplus@yahoo.fr/georgetteka@yahoo.fr; \\ Tel: $0022507250511 / 0022540987331$
}

\begin{abstract}
In Côte d'Ivoire, Solanum nigrum Linn. leaves are consumed at breakfast in rural zones most of the time fortified with peanut paste. Thus, in this study, this meal was evaluated by appropriate methods for its nutrients content in order to determine if it can cover the needs of the morning of famers. The results showed that the macronutrients contents were $2.27 \mathrm{~g}, 1.7$ and $0.23 \mathrm{~g}$ per $100 \mathrm{~g}$ of fresh leaves respectively for proteins, carbohydrates and lipids, with an energy value of $17.95 \mathrm{kcal}$. That represents $2.99 \%$ of the energetic intake a low-activity adult man needs at breakfast which is $600 \mathrm{kcal}$. However, after cooking and fortification of these leaves with peanut paste, this energy value increased to reach the value of $600.69 \mathrm{kcal}$. This covers well the energy value that a low-activity adult man needs at breakfast. These leaves content also minerals $(\mathrm{Ca}, \mathrm{Fe}, \mathrm{Mg}$, $\mathrm{Mn}, \mathrm{K}, \mathrm{Na}, \mathrm{Zn}$ and $\mathrm{Cu}$ ), fibers and vitamin $\mathrm{A}$. This nutrients intake was significantly improved after the fortification with peanut paste. Thus, as these leaves fortified with peanut paste are consumed mainly by farmers before starting their daily activities, we can conclude that this meal covers their nutritional needs of the morning.
\end{abstract}

(C) 2019 International Formulae Group. All rights reserved

Keywords: Dietary plant, macronutrients, minerals, energy value.

\section{INTRODUCTION}

Many diseases are related to nutritional imbalances. Indeed, good nutrition is an indisputable factor of good health. To stay healthy, the body needs a certain proportion of carbohydrates, fats and proteins but also vitamins and minerals. All these components can be found in plants (Jansen van Rensburg et al., 2004). Indeed, the nature has provided abundant plants wealth for all living creatures, which possess medicinal virtues (Bhatti et al., 1998; Kouadio et al., 2011). In Africa the survival of 60 to $80 \%$ of poor people depends directly on natural resources (Betti et al. 2016). The important values of some of these plants have long been published but a large number of them remain are less explored. In West Africa, about 350 species have been listed and described by Baumer (1995) and Uusiku et al. (2010). Among these plants, there is Solanum nigrum Linn., a wild plant widespread in tropical zones. It belongs to the family of Solanaceae and the genus Solanum. Medically, this plant is frequently used as a valuable ingredient for clinical traditional Chinese medicine cancer therapy (An et al., 
2006). Chinese people have used the leaves of this plant to alleviate inflammation and edema through its antipyretic and diuretic effect (Zakaria et al., 2006). Hepatoprotective activity of this plant is well established (Lin et al., 2008). Studies have been conducted providing evidence for the antitumor potential of this plant, including liver, stomach, lung, bladder, breast, and colon cancer (An et al., 2006). Leaves of this plant have been used as traditional folk medicine by the inhabitants of southern India to treat mouth ulcers.In addition to the medicinal field, the leaves of Solanum nigrum are used for culinary purpose. Indeed, in Côte d'Ivoire, although, Atchibri et al. (2012) reported that leafy vegetables do not occupy a prominent place in dietary habits, the leaves of Solanum nigrum are cooked, grounded and fortified with peanut paste. The whole leaves with peanut paste is consumed by all the family (men, women and children) in rural zones before the beginning of the daily activities in farms.

According to the settlement 1169/2011 of the European Union, breakfast, fist meal of the day, must cover the needs of the morning $(25 \%$ of the daily energy value). Unfortunately, in most of the rural zones in African countries including Côte d'Ivoire, it is noted an insufficiency of the nutrients intake in the daily diet. Thus in this study, the leaves of Solanum nigrum were evaluated for their nutrients content before and after cooking and fortification with peanut paste in order to determine if the meal obtained can cover the needs of farmers at breakfast.

\section{MATERIALS AND METHODS \\ Biological material}

In this study, the leaves of Solanum nigrum Linn. And peanut (Arachis hypogaea) seeds (Figure 1 and Figure 2 respectively) were used. These leaves and peanutsseeds were collected from rural zones of the central part of Côte d'Ivoire. These leaves are widely known and consumed by Ivorian population for many years now. Thus, once collected, they were identified by the National Floristic Centre of Côte d'Ivoire for a confirmation of the name.
Determination of the nutrients content of the fresh leaves $(100 \mathrm{~g})$ and of the leaves after cooking and fortification with peanut paste (100 g)

\section{Determination of moisture content}

The method used for the determination of the moisture was the standard ISO 6496:1999. In practical terms, $100 \mathrm{~g}$ leaves were dried in an incubator at $103{ }^{\circ} \mathrm{C}$ until constant weight. The humidity evaporated constituted the moisture content of leaves.

This moister content was determined by calculating the difference between the weight of the fresh leaves and the constant weight of the dried leaves. Three essays were done.

\section{Determination of proteins content}

The method used for the determination of proteins content was the standard ISO 5983-1:2005 (method of Kjeldahl). This analysis consisted in digestion by heating the sample (leaves or leaves fortified by peanut paste) in the presence of sulfuric acid, anhydrous sodium sulfate and copper.The solution in the digestion flask is then made alkaline by addition of sodium hydroxide.The nitrogen content is then estimated by titration of the ammonium borate formed with standard sulfuric. The nitrogen concentration of the sample was determined using the following equation:

$\% N=\frac{x \text { moles }}{1000 \mathrm{~cm}^{3}} \times \frac{\left(v_{s}-v_{b}\right) \mathrm{cm}^{3}}{m \mathrm{~g}} \times \frac{14 \mathrm{~g}}{\text { moles }} \times 100$

Where $v \mathrm{~s}$ and $v \mathrm{~b}$ are the titration volumes of the sample and blank, and $14 \mathrm{~g}$ is the molecular weight of nitrogen N. Once the nitrogen content has been determined, it is converted to a protein content: \% Protein $=\mathrm{F}$. $\% \mathrm{~N}$. Where $\mathrm{F}=6.25$. Three essays were done.

\section{Determination of fibers content}

The method used for the determination of the fibers content was the standard NF V 03-040:1993. This method consisted firstly in enzymatic digestion of the sample (leaves or leaves fortified by peanut paste) by $\alpha$ amylase. The homogenate obtained was precipitated and filtrated. The residue obtained was used for ash analysis. 
The fibers content $=$ Weight $($ residue $)-$ Weight (ash + proteins). Three essays were done.

\section{Determination of lipids content}

The lipids content was determined by the method of the settlement CE $N^{\circ} 152 / 2009$ of European Union.The extraction was made in Soxhlet extractor used hexane at $68{ }^{\circ} \mathrm{C}$ for 12 hours. The solvent was then removed from the extract in a rotary evaporator at $40{ }^{\circ} \mathrm{C}$ under vacuum. The amount of lipid recovered was determined as below:

Mass of lipid $=($ weight of the flask + boiling chips + extracted oil) - (weight of the flask + boiling chips).

The lipids content was then determined as below:

Lipid content $(\%)=$ mass of lipid extracted $(\mathrm{g}) /$ sample weight $(\mathrm{g}) \times 100$.Three essays were done.

\section{Determination of raw ash contents}

The raw ash contents was determined by method ISO 2171:2007. The sample (leaves or leaves fortified by peanut paste) was dried in an incubator at $103^{\circ} \mathrm{C}$ until constant weight. The dried sample was then burned at $500{ }^{\circ} \mathrm{C}$. Three essays were done. The ash content was expressed on dry basis:

$$
\% A \text { sh (dry basis) }=\frac{M_{A S H}}{M_{D R Y}} \times 100
$$

$\mathrm{M}_{\mathrm{ASH}}$ is the mass of ash and $\mathrm{M}_{\mathrm{DRY}}$ is the mass of dried sample obtained after drying until constant weight of the sample.

\section{Determination of carbohydrates content}

The carbohydrates content of the leaves was obtained by the difference between the dry matter content and the sum of the protein, lipid, fibers and raw ash contents of the sample (Albalasmeh, 2013).

\section{Determination of the minerals content}

The atomic absorption spectrometric method (standard ISO 6869: 2000) was used for the determination of calcium $(\mathrm{Ca})$, copper
$(\mathrm{Cu})$, iron $(\mathrm{Fe})$, magnesium $(\mathrm{Mg})$, manganese $(\mathrm{Mn}), \quad$ potassium $(\mathrm{K}), \quad$ sodium $(\mathrm{Na})$, phosphorus (P) and zinc (Zn) ). For this study, the samples were digested by microwave. The contents of minerals were determined by Absorption/flame atomic emission spectrometer VARIAN Spectra AA 110. The standard minerals from Central Laboratory of Food Hygiene of LANADA (Abidjan, Côte d'Ivoire) were used for quality control.For each mineral, three essays were done.

\section{Determination of the vitamins}

The vitamins (Vitamin A, vitamin E, vitamin B1, vitamin B2, vitamin B6 and vitamin B9) contents were determined by the method of the settlement CE $\mathrm{N}^{\circ} 152 / 2009$ of European Union. After extraction by appropriate solvents, the vitamins were analyzed by reversed-phase HPLC without separation of isomers using standards of these vitamins. Three essays were done for each vitamin.

\section{Determination of the energy value}

The energy value is the energy released by the combustion of macronutrients which are proteins, carbohydrates and lipids contained in the diet. This energy value was determined taking into account their ATWATER coefficient: $4 \mathrm{kcal}, 4 \mathrm{kcal}$, and 9 kcal respectively for proteins, carbohydrates and lipids (Greenfieldand Southgate, 1992). It's expressed in kcal and calculated from the following formula: $\mathbf{E}(\mathbf{k c a l})=(9 \times \mathbf{L})+(4 \times \mathbf{P})$ $+(4 \times C)$

With: L: lipids, P: Proteins and C: Carbohydrates.

\section{Statistical analysis}

The statistical analysis of data wasmade by Analysis of Variance (ANOVA) using 5\% level of significance. The statistical package used was IBM SPSS Statistics version 20. Tukey's Multiple Comparison test was used to identify these differences. 


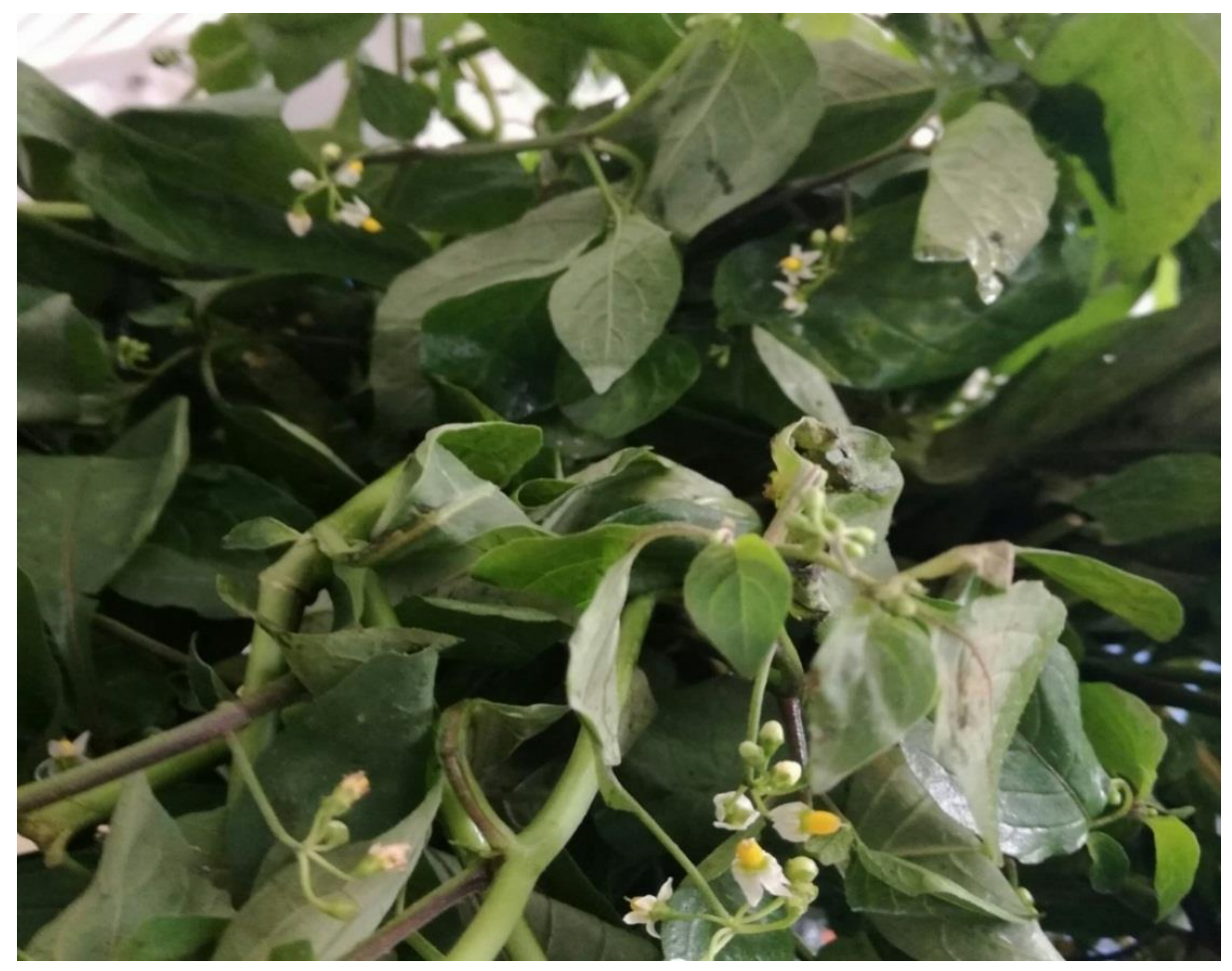

Figure 1: Solanum nigrum Linn. fresh leaves.

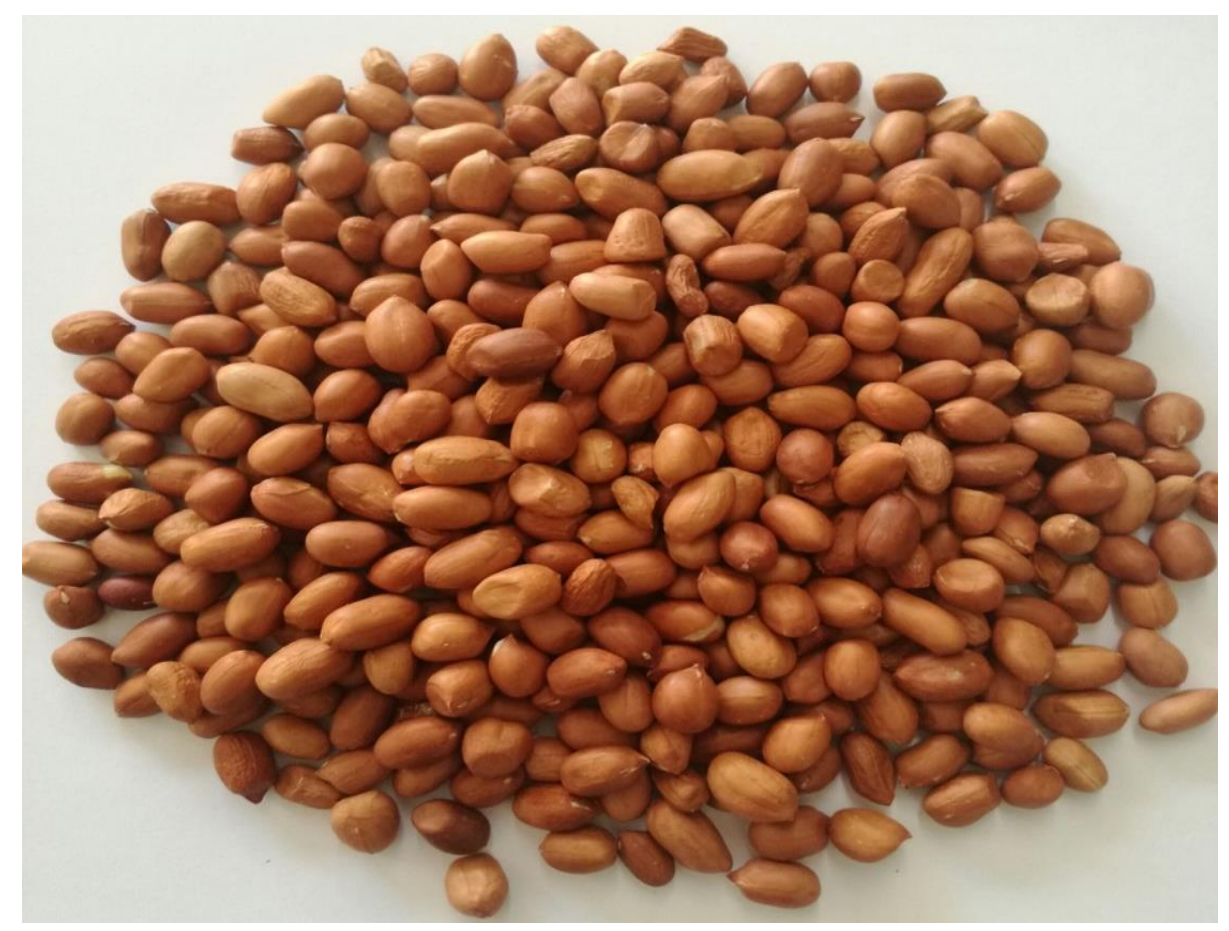

Figure 2: Peanut (Arachis hypogaea) seeds. 


\section{RESULTS}

The results obtained showed that the leaves of Solanum nigrum content macronutrients with proportions of $2.27 \mathrm{~g}, 1.7$ and $0.23 \mathrm{~g}$ per $100 \mathrm{~g}$ of fresh leaves respectively for proteins, carbohydrates and lipids. That represents $2.27 \%, 1.7 \%$ and $0.23 \%$ respectively for proteins, carbohydrates and lipids (Table 1). These proportions of macronutrients provide an energy value of $17.95 \mathrm{kcal}$ per $100 \mathrm{~g}$ of leaves (Table 3). This energy value represents $2.99 \%$ of the energy value a low-activity adult man needs at breakfast which is $600 \mathrm{kcal}$.

However, after cooking and fortification of $100 \mathrm{~g}$ of these leaves with 100 $\mathrm{g}$ of peanut paste, the analysis done showed that the proportions of proteins, carbohydrates and lipids increased to reach the values of 22 $\mathrm{g}, 14.03 \mathrm{~g}$ and $50.73 \mathrm{~g}$ respectively. This represents 22\%, $14.03 \%$ and $50.73 \%$ respectively for proteins, carbohydrates and lipids (Table 2). These amounts of macronutrients provided energy of 600.69 kcal (Table 3). It's noted a significant difference between the energy value provided by the fresh leaves and that provided by the leaves after cooking and fortification with peanut paste $(\mathrm{P}<0.05)$.

The minerals found in the fresh leaves were $\mathrm{Ca}, \mathrm{Fe}, \mathrm{Mg}, \mathrm{Mn}, \mathrm{K}, \mathrm{Na}, \mathrm{Zn}$ and $\mathrm{Cu}$ with proportions of $225.9 \mathrm{mg}, 9.65 \mathrm{mg}, 61.56 \mathrm{mg}$, $1.6,1064.2 \mathrm{mg}, 216.36 \mathrm{mg}, \mathrm{O} .8 \mathrm{mg}$ and 1.5 $\mathrm{mg}$ per $100 \mathrm{~g}$ of leaves respectively.

The levels of these micronutrients increased significantly to reach the values of
$279.9 \mathrm{mg}, 11.85 \mathrm{mg}, 219.56 \mathrm{mg}, 1.6 \mathrm{mg}$, $1697.2 \mathrm{mg}, 297.36 \mathrm{mg}, 0.8 \mathrm{mg}$, and $1.5 \mathrm{mg}$ respectively for these minerals mentioned above after cooking and fortification of the leaves with peanut paste. The levels of these minerals obtained before and after cooking and fortification of the leaves with paste are significantly different $(\mathrm{P}<0.05)$. The whole leaves fortified with peanut paste provided also phosphorus $(\mathrm{P})$ with an amount of 339 $\mathrm{mg}$ per $100 \mathrm{~g}$ of sample. The amounts of these minerals $(\mathrm{Ca}, \mathrm{Fe}, \mathrm{Mg}, \mathrm{Mn}, \mathrm{K}, \mathrm{Zn}, \mathrm{Cu}$ and $\mathrm{P}$ ) represent respectively $34.99 \%, 84.64 \%$, $58.55 \%, 80.00 \%, 84.86 \%, 8.00 \%, 150.00 \%$ and $48.43 \%$ of the daily intakes recommended (Table 4).

These leaves fortified with peanut paste provided vitamins such as vitamin $\mathrm{E}$, vitamin $\mathrm{B} 1$, vitamin $\mathrm{B} 2$, vitamin $\mathrm{B} 6$ and vitamin B9 with amounts of $8.51 \mathrm{mg}, 0.72$ $\mathrm{mg}, 0.12 \mathrm{mg}, 0.27 \mathrm{mg}$ and $100 \mu \mathrm{g}$ per $100 \mathrm{~g}$ of sample, while, in the sample before fortification with peanut paste, the only vitamin found was vitamin A with an amount of $385 \mu \mathrm{g}$ (Table 2). The amounts of these vitamins represent $48.13 \%, 70.92 \%, 65.45 \%$, $8.57 \%, 19.29 \%$ and $50 \%$ of the daily intakes recommended respectively for vitamin A, vitamin $\mathrm{E}$, vitamin $\mathrm{B} 1$, vitamin $\mathrm{B} 2$, vitamin B6 and vitamin B9 (Table 4).

In addition to all the nutrients mentioned above, the fibers were also found in these leaves. Indeed, the total fibers content which was $2.15 \%$ in the sample without peanut paste increased to reach a proportion of $4 \%$ in the leaves fortified with peanut paste.

Table 1: Nutrients content of Solanum nigrum L. fresh leaves.

\begin{tabular}{llllll}
\hline Nutrients & Essay 1 & Essay 2 & Essay 3 & Mean & $\begin{array}{l}\text { Standard } \\
\text { deviation (SD) }\end{array}$ \\
\hline Moisture (\%) & 91.23 & 93.62 & 89.5 & $\mathbf{9 1 . 4 5}$ & 2.07 \\
Proteins (\%) & 2.32 & 2.27 & 2.22 & $\mathbf{2 . 2 7}$ & 0.05 \\
Carbohydrates (\%) & 1.76 & 1.9 & 1.44 & $\mathbf{1 . 7}$ & 0.24
\end{tabular}




\begin{tabular}{llllll} 
Fibers $(\%)$ & 2.12 & 2.22 & 2.11 & $\mathbf{2 . 1 5}$ & 0.06 \\
Lipids $(\%)$ & 0.23 & 0.24 & 0.22 & $\mathbf{0 . 2 3}$ & 0.01 \\
Rawash contents $(\%)$ & 2.22 & 2.12 & 2.26 & $\mathbf{2 . 2}$ & 0.07 \\
$\mathrm{Ca}(\mathrm{mg} / 100 \mathrm{~g})$ & 229.2 & 219.6 & 228.9 & $\mathbf{2 2 5 . 9}$ & 5.46 \\
$\mathrm{Fe}(\mathrm{mg} / 100 \mathrm{~g})$ & 9.54 & 10.12 & 9.29 & $\mathbf{9 . 6 5}$ & 0.43 \\
$\mathrm{Mg}(\mathrm{mg} / 100 \mathrm{~g})$ & 60.26 & 62.26 & 62.16 & & \\
$\mathrm{Mn}(\mathrm{mg} / 100 \mathrm{~g})$ & 1.76 & 1.54 & 1.5 & $\mathbf{6 1 . 5 6}$ & 1.13 \\
$\mathrm{~K}(\mathrm{mg} / 100 \mathrm{~g})$ & 1071.62 & 1041.32 & 1079.66 & $\mathbf{1 0 6 4 . 2}$ & 20.22 \\
$\mathrm{Na}(\mathrm{mg} / 100 \mathrm{~g})$ & 218.6 & 209.6 & 220.88 & $\mathbf{2 1 6 . 3 6}$ & 5.96 \\
$\mathrm{Zn}(\mathrm{mg} / 100 \mathrm{~g})$ & 0.81 & 0.77 & 0.82 & & \\
$\mathrm{Cu}(\mathrm{mg} / 100 \mathrm{~g})$ & 1.53 & 1.58 & 1.39 & $\mathbf{1 . 5}$ & 0.14 \\
$\mathrm{Vitamin} \mathrm{A}(\mu \mathrm{g} / 100 \mathrm{~g})$ & 379.31 & 389.12 & 386.57 & $\mathbf{3 8 5}$ & 5.09 \\
\hline
\end{tabular}

Table 2: Nutrients content of Solanum nigrum L. leaves after cooking and fortification with peanut paste.

\begin{tabular}{llllll}
\hline Nutrients & Essay 1 & Essay 2 & Essay 3 & Mean & $\begin{array}{l}\text { Standard } \\
\text { deviation (SD) }\end{array}$ \\
\hline Moisture (\%) & 5.9 & 6.22 & 6 & $\mathbf{6 . 0 4}$ & 0.16 \\
Proteins (\%) & 21 & 21.9 & 23.1 & $\mathbf{2 2}$ & 1.05 \\
Carbohydrates (\%) & 13.8 & 14.49 & 13.8 & $\mathbf{1 4 . 0 3}$ & 0.40 \\
Fibers (\%) & 4 & 3.3 & 4.7 & $\mathbf{4}$ & 0.70 \\
Lipids (\%) & 50.2 & 50.95 & 51.04 & $\mathbf{5 0 . 7 3}$ & 0.46 \\
Rawash content (\%) & 3.1 & 2.8 & 3.7 & $\mathbf{3 . 2}$ & 0.46 \\
Ca (mg/100g) & 278.9 & 276.4 & 284.4 & $\mathbf{2 7 9 . 9}$ & 4.09 \\
Fe (mg/100g) & 12.75 & 11 & 11.8 & $\mathbf{1 1 . 8 5}$ & 0.88
\end{tabular}




\begin{tabular}{|c|c|c|c|c|c|}
\hline $\mathrm{Mg}(\mathrm{mg} / 100 \mathrm{~g})$ & 217.4 & 220 & 221.28 & 219.56 & 1.98 \\
\hline Mn (mg/100g) & 1.2 & 2 & 1.6 & 1.6 & 0,40 \\
\hline $\mathrm{K}(\mathrm{mg} / 100 \mathrm{~g})$ & 1698.6 & 1695 & 1698 & 1697.2 & 1,93 \\
\hline $\mathrm{Na}(\mathrm{mg} / 100 \mathrm{~g})$ & 303.08 & 292 & 297 & 297.36 & 5.55 \\
\hline Zn (mg/100g) & 0.6 & 1.1 & 0.7 & 0.8 & 0.26 \\
\hline $\mathrm{Cu}(\mathrm{mg} / 100 \mathrm{~g})$ & 1.2 & 1.5 & 1.8 & 1.5 & 0.30 \\
\hline $\mathrm{P}(\mathrm{mg} / 100 \mathrm{~g})$ & 333 & 343 & 341 & 339 & 5.29 \\
\hline Vitamin A $(\mu \mathrm{g} / 100 \mathrm{~g})$ & 385 & 380 & 390 & 385 & 5.00 \\
\hline Vitamin E (mg/100g) & 8 & 7.8 & 9.73 & 8.51 & 1.06 \\
\hline Vitamin B1 $(\mathrm{mg} / 100 \mathrm{~g})$ & 0.81 & 0.7 & 0.65 & 0.72 & 0.08 \\
\hline Vitamin B2 (mg/100g) & 0.1 & 0.18 & 0.08 & 0.12 & 0.05 \\
\hline Vitamin B6 (mg/100g) & 0.24 & 0.29 & 0.3 & 0.27 & 0.04 \\
\hline Vitamin B9 $(\mu \mathrm{g} / 100 \mathrm{~g})$ & 102 & 101 & 97 & 100 & 2.65 \\
\hline
\end{tabular}

Table 3: Energetic intake of Solanum nigrum L. leaves without fortification and with fortification with peanut paste.

\begin{tabular}{lll}
\hline & $\begin{array}{l}\text { Solanum nigrum } \\
\text { fresh leaves }\end{array}$ & $\begin{array}{l}\text { Solanum nigrum L. leaves after } \\
\text { cooking and supplementation with } \\
\text { peanut paste }\end{array}$ \\
\hline Proteins (g) & $2.27 \pm 0.05$ & $22 \pm 1.05$ \\
Carbohydrates (g) & $1.7 \pm 0.24$ & $14,03 \pm 0.40$ \\
Lipids (g) & $0.23 \pm 0.01$ & $50,73 \pm 0.46$ \\
\hline Energy value (kcal) & $\mathbf{1 7 . 9 5}^{\mathbf{a}}$ & $\mathbf{6 0 0 . 6 9}^{\mathbf{b}}$ \\
\hline The energetic intake in both case are significantly different at the 0.05 level.
\end{tabular}

The energetic intake in both case are significantly different at the 0.05 level. 
Table 4: Minerals and vitamins intake of Solanum nigrum leaves after cooking and fortification with peanut paste compared to the daily intake recommended.

\begin{tabular}{|c|c|c|c|c|}
\hline $\begin{array}{l}\text { Minerals an } \\
\text { vitamins }\end{array}$ & & $\begin{array}{l}\text { Daily intakes } \\
\text { recommended of } \\
\text { the settlement } \\
1169 / 2011 \text { (DIR) }\end{array}$ & $\begin{array}{l}\text { Minerals and vitamins of the } \\
\text { leaves after cooking and } \\
\text { fortification with peanut } \\
\text { paste }\end{array}$ & $\begin{array}{l}\text { The whole leaves and } \\
\text { peanut paste / Daily } \\
\text { intakes recommended } \\
(\%)\end{array}$ \\
\hline $\mathrm{Ca}(\mathrm{mg} / 100 \mathrm{~g}$ & & 800 & $279.9 \pm 4.09$ & 34.99 \\
\hline $\mathrm{Fe}(\mathrm{mg} / 100 \mathrm{~g})$ & & 14 & $11.85 \pm 0.88$ & 84.64 \\
\hline $\mathrm{Mg}(\mathrm{mg} / 100$ & & 375 & $219.56 \pm 1.98$ & 58.55 \\
\hline $\mathrm{Mn}(\mathrm{mg} / 100$ & & 2 & $1.6 \pm 0.40$ & 80,00 \\
\hline $\mathrm{K}(\mathrm{mg} / 100 \mathrm{~g})$ & & 2000 & $1697.2 \pm 1.93$ & 84.86 \\
\hline $\mathrm{Na}(\mathrm{mg} / 100 \mathrm{~g}$ & & - & $297.36 \pm 5.55$ & - \\
\hline $\mathrm{Zn}(\mathrm{mg} / 100 \mathrm{~g}$ & & 10 & $0.80 \pm 0.26$ & 8.00 \\
\hline $\mathrm{Cu}(\mathrm{mg} / 100 \mathrm{~g}$ & & 1 & $1.5 \pm 0.30$ & 150.00 \\
\hline$P(\mathrm{mg} / 100 \mathrm{~g})$ & & 700 & $339 \pm 5.29$ & 48.43 \\
\hline $\begin{array}{l}\text { Vitamin } \\
(\mu \mathrm{g} / 100 \mathrm{~g})\end{array}$ & A & 800 & $385 \pm 5.00$ & 48,13 \\
\hline $\begin{array}{l}\text { Vitamin } \\
(\mathrm{mg} / 100 \mathrm{~g})\end{array}$ & E & 12 & $8,51 \pm 1.06$ & 70.92 \\
\hline $\begin{array}{l}\text { Vitamin } \\
(\mathrm{mg} / 100 \mathrm{~g})\end{array}$ & B1 & 1,1 & $0.72 \pm 0.08$ & 65.45 \\
\hline $\begin{array}{l}\text { Vitamin } \\
(\mathrm{mg} / 100 \mathrm{~g})\end{array}$ & B2 & 1.4 & $0.12 \pm 0.05$ & 8.57 \\
\hline $\begin{array}{l}\text { Vitamin } \\
(\mathrm{mg} / 100 \mathrm{~g})\end{array}$ & B6 & 1.4 & $0.27 \pm 0.04$ & 19.29 \\
\hline $\begin{array}{l}\text { Vitamin } \\
(\mu \mathrm{g} / 100 \mathrm{~g})\end{array}$ & B9 & 200 & $100 \pm 2.65$ & 50 \\
\hline
\end{tabular}




\section{DISCUSSION}

This study has confirmed the fact that no food contains all the nutrients with amounts which meet the needs of the body. Indeed, the results obtained showed that the leaves of Solanum nigrum content proteins, carbohydrates and lipids.

The energy provided by these macronutrients which was $17.95 \mathrm{kcal}$ was not enough to coverthe needs of energy of the morning. Indeed, this represents $2.99 \%$ of the energy value a low-activity adult man needs at breakfast which is $600 \mathrm{kcal}$. This energy value which is $600 \mathrm{kcal}$ represents $25 \%$ of the energy value of the day a low-activity adult man needs according to the settlement 1169/2011 of the European Union. However, after cooking and fortification of the leaves with peanut paste, the energy obtained was $600.69 \mathrm{kcal}$. That covers the energy value a low-activity adult man needs at breakfast. However, this amount of energy is not enough for the needs of the morning of a moderateactivity or high-activity adult man.

Thus, for these last two categories of people, other products such as yam or cassava which are rich in carbohydrates can be added to this meal consumed at breakfast. In addition to the macronutrients found in this meal (leaves fortified by with peanut paste), the presence of minerals such as $\mathrm{Ca}, \mathrm{Fe}, \mathrm{Mg}$, $\mathrm{Mn}, \mathrm{K}, \mathrm{Zn}, \mathrm{Cu}$ and $\mathrm{P}$ was noted. The comparison of the amounts of these minerals to the daily intakes recommended showed that this meal is rich in $\mathrm{Fe}, \mathrm{Mn}, \mathrm{K}$ and $\mathrm{Cu}$. However, the amount of $\mathrm{Cu}$ is above of that recommended in the daily diet by the settlement 169/2011 of the European Union for men and women adults while it's that required for teenagers.Thus a little attention must be paid because according to Lappano et al. (2016), the excess of $\mathrm{Cu}$ can have an impact on occurrence of breast cancer.In opposite to $\mathrm{Cu}$, the absence of selenium (Se) is noted in this meal. This mineral (Se) which plays a role in the fight against cancer must thus be added to the meal by providing other source of this mineral such as dehydrated nuts (Food and Nutrition Board, Institute of Medicine, 2000). As this mineral, each of these micronutrients mentioned above plays an important role in the metabolism of the body. Indeed, calcium $(\mathrm{Ca})$ has an effect on bone health in terms of protection (Park and Weaver, 2012), while the magnesium (mg) can bring down the tension blood pressure, cholesterol levels and is involved in defense systems natural against attacks of any kind.

It is very important for the pregnant woman (Sidor et al., 2016). Iron (Fe) has a vital role in the metabolism of red blood cells (hemoglobin), in muscle function. Its deficiency anemia is the most frequent in infants and children in sub-Saharan Africa (Paganini et al., 2016). Copper $(\mathrm{Cu})$ is involved in the fight against free radicals. Zinc ( $\mathrm{Zn})$ is one of the most important elements involved in the metabolism in humans. It is a mineral antioxidant, membrane stabilizer lipids, and which plays a role in reproductive functions and in maintaining genetic material (Rahman et al., 2016).

It is noted that Solanum nigrum L. is an important source of micronutrients. Indeed, nutritional assessment of African nightshade (Solanum scabrum) which is a plant belonging also to the family of Solanaceae showed micronutrients contents less important than those found in our study (Bogmis et al., 2018).

Among vitamins found in the leaves supplemented with peanut paste, the highest levels were those of vitamin $\mathrm{E}$, vitamin $\mathrm{B} 1$, vitamin B9 and vitamin A. All these vitamins are involved in many biological functions such as construction (growth, development of the skeleton), functioning and maintenance (transformation and use of macronutrients, vision and normal functioning of the muscular system, nervous and immune). All these biological properties show the interest of populations for alimentary plants in the fight against micronutrients, macronutrients and vitamins deficiencies and other diseases.

\section{Conclusion}

This study has shown that the meal composed of Solanum nigrum leaves and peanut paste provides nutrients with amounts which cover the needs of a low-activity adult 
man. Indeed, this meal covers their nutritional intake of the morning.

However, for a moderate-activity or high-activity adult man, other products such as yam or cassava which are rich in carbohydrates can be added to this meal consumed at breakfast. Moreover, this plant is rich in micronutrients essential for the proper functioning of the body. Thus, this plant would be of significant interest to rural populations to overcome many diseases because as to stay healthy, the body needs a certain proportion of carbohydrates, fats and proteins but also vitamins and minerals. It would be necessary to promote a broad consumption of this plant in the house holds because of its certain health benefit.

\section{COMPETING INTERESTS}

The authors declare that they have no competing interests.

\section{AUTHORS' CONTRIBUTIONS}

The title, the statistical analysis and all the contents of the manuscript were exchanged between all co-authors. Quantification of nutrients was supervised by MKK. The manuscript was written by IAK and the correction was made by GAK.

\section{ACKNOWLEDGMENTS}

The authors gratefully acknowledge the Central Laboratory of Food Hygiene of LANADA (Abidjan, Côte d'Ivoire) for all the analysis carried out.

\section{REFERENCES}

Albalasmeh AA, Berhe AA, Ghezzehei TA. 2013. A new method for rapid determination of carbohydrate and totalcarbon concentrations using UV spectrophotometry. Carbohydrate Polymers, 97: 253-261.

Atchibri A, Soro LC, Kouamé C, Agbo EA, Kouadio KKA. 2012. Valeur nutritionnelle des légumes feuilles consommés en Côte d'Ivoire. Int. J. Biol. Chem. Sci., 6(1): 128-135. DOI: http://dx.doi.org/10.4314/ijbcs.v6i1.12
An L, Tang JT, Liu XM, Gao NN. 2006. Review about mechanisms of anti-cancer of Solanum nigrum. Zhongguo Zhongyao Zazhi, 31(15): 1225-1260.

Bhatti GR, Qureshi R, Shah M. 1998. Ethnobotany of Calotropis procera with especial reference to the people of Nara Desert. Sindh Scientific University Research Journal, 5: 13-22.

Baumer M. 1995. Arbres, Arbustes et Arbrisseaux Nourriciers en Afrique Occidentale. Enda Tiers-Monde: Dakar; 260p.

Betti JL, Ngankoué CM, Dibong SD, Singa AE. 2016. Etude ethnobotanique des plantes alimentaires spontanées vendues dans les marchés de Yaoundé, Cameroun. Int. J. Biol. Chem. Sci., 10(4): $\quad 1678-1693 . \quad$ DOI: http://dx.doi.org/10.4314/ijbcs.v10i4.19

Bogmis MNN, Ngwa FA, Manga GA. 2018. Evaluation nutritionnelle de la morelle africaine au Cameroun. Int. J. Biol. Chem. Sci., 12(1): 62-74. DOI: http://dx.doi.org/10.4314/ijbcs.v12i1.5

Dietary Reference Intakes for Vitamin C, Vitamin E, Selenium, and Carotenoids. 2000. Food and Nutrition Board, Institute of Medicine.

Greenfield H, Southgate DAT. 1992. Food composition data: Production, management and use. p156.

ISO 6496: 1999. Aliments des animaux Détermination de la teneur en eau et en d'autres matières volatiles. $2^{e} e ́ d$. ISO, $8 \mathrm{p}$.

ISO 6869: 2000. Aliments des animaux Détermination des teneurs en calcium, cuivre, fer, magnésium, manganèse, potassium, sodium et zinc - Méthode par spectrométrie d'absorption atomique. $I^{e}$ éd. ISO, 16p.

ISO 5983-1: 2005. Aliments des animaux Dosage de l'azote et calcul de la teneur en protéines brutes - Partie 1: Méthode Kjeldahl. $l^{e} e ́ d$. ISO, 10p.

ISO 2171:2007. Céréales, légumineuses et produits dérivés - Dosage du taux de cendres par incinération. $4^{e} e ́ d$. ISO, $11 \mathrm{p}$. 
Jansen van Rensburg WS, Venter SL, Netshiluvhi TR, Ven Der Heever E, Vorster HJ, JA de Ronde. 2004. Role of indigenous leafy vegetables in Combatting Hunger and Malnutrition. South Afr. J. Bot., 70(1): 52-59.

Lin HM, Tseng HC, Wang CJ, Lin JJ, Lo CW, Chou FP. 2008. Hepatoprotective effects of Solanum nigrum Linn extract against CCl4-iduced oxidative damage in rats. Chemico-Biological Interactions, 171(3):283-293.

Kouadio AI, Oulahai N, Nguyen TP, ADT I, Degraeve P. 2011. Study of the antimicrobial activities of Solanum indicum ssp. Distichum (Schumach. and Thonning 1827) fruits ("gnangnan" berries) from a tropical humid zone (Côte d'Ivoire). Int. J. Biol. Chem. Sci., 5

1190-1200.

DOI: 10.4314/ijbcs.v5i3.72254

Lappano R, Malaguarnera R, Belfiore A, Maggiolini M. 2016. Recent advances on the stimulatory effects of metals in breast cancer. Mol. Cell. Endocrinol., 5 (457): 49-56. DOI: 10.1016/j.mce.2016.10.017

NF V03-040. 1993. Produits agricoles et alimentaires - Détermination de la cellulose brute - Méthode générale. NF V03-040.

Paganini D, Uyoga MA, Zimmermann MB. 2016. Iron Fortification of Foods for Infants and Children in Low-Income
Countries: Effects on the Gut Microbiome, Gut Inflammation, and Diarrhea. Nutrients, 8(8): 494.

Park CY, Weaver CM. 2012. Review Vitamin D Interactions with Soy Isoflavones on Bone after Menopause: A Review. Nutrients, 4: 1610-1621.

Rahman S, Ahmed T, Rahman AS, Alam N, Ahmed AMS, Ireen S, Chowdhury IA, Chowdhury FP, Rahman SMM. 2016. Status of zinc nutrition in Bangladesh: the underlying associations. J. Nutr. Sci., 5(25): 1-9.

Settlement $N^{\circ} 1169 / 2011$ of the European Union.

Settlement $N^{\circ} 152 / 2009$ of the European Union.

Sidor P, Głąbska D, Włodarek D. 2016. Analysis of the dietary factors contributing to the future osteoporosis risk in young Polish women. Rocz. Panstw. Zakl. Hig., 67(3): 279-85.

Uusiku NP, Oelofse A, Duodu KG, Megan JB, Faber M. 2010. Nutritional value of leafy vegetables of sub-Saharan Africa and their potential contribution to human health: A review. J. F. Comp. Anal., 23: 499-509.

Zakaria ZA, Gopalan HK, H. Zainal et al. 2006. Antinociceptive, antiinflammatory and antipyretic effects of Solanum nigrum chloroform extract in animal models. Yakugaku Zasshi, 126(11): 1171-1178. 